\title{
The Entwining of Trade and Environmental Policies
}

\author{
Kym Anderson
}

$\mathrm{E}$ nvironmental issues are becoming increasingly enmeshed with economic policy debates, including trade policy discussions (Anderson \& Blackhurst, 1992; Low, 1992; Whalley \& Uimonen, 1994). This greening of national and international politics offers many economic opportunities, as well as challenges, to the Australian community generally and to the primary export sectors in particular. Australian exporters could gain significantly from this development, but whether they ultimately are net beneficiaries depends heavily on the policy choices to be made both here and abroad. There is a considerable risk that the policies adopted in response to environmental concerns will reduce welfare in many countries, including our own, and possibly even damage rather than improve the natural environment.

Australia's primary exporters have been concerned mainly with the erosion of their export competitiveness (because of the adoption of ever-more stringent environmental standards in Australia) and with the reduced incentive to invest further (because of policy uncertainty). This concern has a clear parallel with the uncertainty over property rights because of Mabo. But in addition to this direct effect of the greening of domestic politics on Australian investment and exports, there are two important indirect effects. One is the impact of environmental policies in other countries on the competitiveness of Australian exporters in international markets. The other - less obvious, but potentially more important - is the effect of linking environment to trade policies on the international trading system as a whole. This article examines each of those two indirect effects, and then draws out some implications for Australia.

\section{The Impact of Environmental Policies Abroad on Australia's Export Com- petitiveness $^{1}$}

Concern about the natural environment (and for product safety) fluctuates with the business cycle. But the long-run trend of concern is clearly upward (especially in

\footnotetext{
${ }^{1}$ An elaboration of points made in this section can be found in Anderson (1993). See also Leonard (1988) and MacNeill et al. (1991).
}

Kym Anderson is Professor of Economics at the University of Adelaide. 
the more developed economies) partly because, despite uncertainties, the scientific basis for many of these concerns is thought to be more solid as research proceeds, and partly because the demands for the services of the natural environment increase with rising incomes. These services include clean air, potable water and filtered sunlight; the capacity to absorb waste; and pleasure from visiting or even just knowing of the existence of unspoilt wilderness areas. In fact, the demand for environmental services tends to grow faster than demand for many other goods and services in middle- and high-income countries. But the supply of these environmental services is not unlimited, and for many of them the markets necessary for rationing their use are incomplete or yet to emerge.

To help overcome this market imperfection, the more advanced economies are establishing institutional structures for arriving at something approaching a social consensus on appropriate environmental policies, for allocating clearer property rights, and for implementing and enforcing policies (Grossman, 1994). These developments are tending to occur faster as an economy's income grows faster, and they tend to begin at a lower level of per capita income the more densely populated the economy, other things equal.

As a resource-rich, lightly populated economy, Australia has a comparative advantage in goods and services whose production requires relatively intensive use of the natural environment: land for farming and grazing, raw materials for energy, minerals and metals, coastal areas for tourism, open spaces for the discharge of pollutive industries to be dissipated, and so on. That comparative advantage is strengthening with economic growth abroad, and more so the faster other economies grow relative to ours and the more that growth abroad is concentrated in densely populated middle- and upper-income countries (as it has been, notably in East Asia). That is, our terms of trade are improving and we are sharing some of the benefits of their faster economic growth. We would gain even if those countries did not change their environmental policies in the course of their economic growth; but we are gaining additionally to the extent that they are raising their environmental standards and charges and thereby effectively increasing their demand for the goods and services of our natural environment that are embodied in our exports.

An obvious example is agriculture. Because land in Australia is relatively cheap, our farmers use relatively few agricultural chemicals (such as fertiliser, pesticides, animal growth hormones) which are effectively substitutes for land. Consequently, Australian food contains few chemical residues: a feature we can, and are, increasingly exploit in marketing our farm products abroad. Furthermore, in so far as any taxes or restrictions are imposed on the use of farm chemicals in Australia, they are likely to be less severe than those imposed in more densely populated and higher-income countries. ${ }^{2}$ Hence the net impact of the greening of farm policies at home and abroad on the export competitiveness of Australian farmers is likely to

2 This is likely to be least so for chemicals that end up in waterways, given Australia's relative scarcity of fresh water. 
be positive: likewise for mining and other producers who take advantage of our abundance of natural resources.

Australian exporters would be delighted if the story could end here; but unfortunately it cannot, for several reasons. One is that foreign producers who are becoming less competitive because of their government's imposition of stricter environmental standards and charges are demanding higher import barriers to protect them from that loss in competitiveness. Such protectionism is unwarranted on economic efficiency grounds, since the environmental standard is aiming to eliminate an unjustifiable implicit subsidy rather than add an unjustifiable tax. Yet sometimes it is the workers rather than the owners of industries who are demanding protection, afraid that the owners will transfer their operations offshore to locations with more lenient environmental standards, so destroying local jobs.

Another complication is that environmental concerns are taking on more of an international and even global orientation, well beyond the earlier intra-national or trans-border concerns with neighbouring countries. Possible climate changes and ozone depletion prompt concem about the emission of carbon or the use of CFCs not just at home but also abroad. The NIMBY (not-in-my-back-yard) phenomenon is becoming less relevant as awareness increases that relocation of a pollutive industry to a country with laxer environmental standards may well increase global pollution. The irony is that that relocation and increased environmental damage may have been stimulated by the raising of environmental standards in one's own country!

Such pressures are likely to increase as the world economy becomes more integrated and more countries begin to industrialise, particularly since global population and consumption growth will be concentrated in these poor but modernising countries for the foreseeable future. Yet they are among the countries where the new institutions to reduce environmental degradation will be slow in coming, because the costs of sacrificing consumption of material goods in order to achieve higher environmental standards weigh much more heavily in poorer than richer economies. Moreover, national differences in willingness and capacity to preserve the natural environment apply not just to physical pollution. They apply also to the abuse of animals, species extinction, and the logging or flooding of pristine wilderness areas from which people derive varying degrees of aesthetic pleasure, regardless of national boundaries.

Since personal values play an important part in international debates on these issues, the scope for friction between countries is considerable. Yet cooperation between sovereign states is required for efficient solutions to such international environmental problems. It is therefore not surprising that institutional innovations to address these concerns have been slow in coming - certainly much slower than environmental groups in some rich countries would like. It is out of frustration over the pace of progress towards international environmental agreements that such groups have turned their attention to one of the few instruments they perceive their national governments to have for influencing environmental outcomes in other countries, namely, trade policy. 


\section{Trade Policy and Environmental Objectives}

Consider the recent dispute between the United States and Mexico over the alleged use of dolphin-unfriendly nets by Mexican tuna fishermen. US environmentalists, distressed at the netting of dolphin by American tuna fishermen, succeeded in getting the practice stopped - only to find the reduced domestic supply of tuna being made up by imports from Mexico. The remaining US tuna fishermen therefore joined environmentalists in calling for a ban on those imports, even though it is impossible to tell whether a particular batch of tuna was caught in dolphin-unfriendly nets or otherwise. The motive for US policy action in this case is evidently a mixture of traditional competitiveness concerns and a concern felt by some in the US (not entirely shared elsewhere) for the global commons and/or for the welfare of dolphins. And the GATT's dispute panel argued in support of Mexico's objection to the import ban partly because the policy was incapable of distinguishing between the dolphin-friendly and dolphin-unfriendly product (whereas it would not have objected to a ban on the sale of tuna products unable to carry the label 'dolphinsafe', for that ban would have applied equally to domestic and imported goods). ${ }^{3}$

Such use of trade measures to address environmental issues should concern the world at large, and Australian exporters in particular, for at least three reasons. First, trade measures are typically not first-best instruments for achieving environmental objectives, so their use in place of more efficient instruments reduces the level and growth of economic welfare unnecessarily, and may even add to rather than reduce environmental degradation (see Anderson, 1992a). Second, concern for the environment may be used (or rather abused) as an excuse to raise trade barriers in ways that are difficult to prove to be inconsistent with a country's obligations under GATT. Accepting the US tuna ban, for example, would have opened a large loophole in the GATT for any country unilaterally to apply trade restrictions not for the purpose of enforcing its own laws within its jurisdiction but to impose its standards on other countries and/or to effectively override previous commitments not to raise import barriers. Third, if it leads to an escalation in trade disputes, it could be followed by retaliation and counter-retaliation, the result of which would be to undermine the multilateral trading system's provision of predictable market access opportunities on which the prosperity of small open economies such as Australia depends.

Some environmentalists would welcome the demise of the GATT rules-based trading system, wrongly believing that GATT is bad for the environment. They believe this for two reasons. One is that it appears to undermine their efforts to raise environmental standards (as in the tuna-dolphin example mentioned above), even though there is nothing in the General Agreement that precludes a country from applying measures to protect human, animal or plant life or health within its jurisdiction. The other is that GATT's purpose is to promote trade liberalisation, two effects of which are to boost global incomes and to cause some international

${ }^{3}$ A discussion of this issue can be found in GATT (1992:27). 
relocation of production and consumption. Both of these effects worry some environmentalists, yet they need not.

\section{Economic Growth and the Environment}

Consider first the economic growth point. Some believe an expansion of global production and hence consumption is undesirable simply because they think it will increase demands on the natural environment. This is a neo-Malthusian view of the world that is as misguided as Malthus's original concern that our growing population would be incapable of feeding itself. It ignores the fact that income growth brings with it numerous changes in behaviour patterns. One such change, already noted, is that as incomes rise in response to trade reforms, more-stringent environmental policies tend to be implemented. This is because the demand for such policies rises with income: they are both more desired and more affordable. As well, higher incomes in poorer countries lead eventually to lower population growth rates, which reduces pressure on both rural and urban environments. And as the value of poor people's time in developing countries increases as trade liberalisation boosts the demand for labour, the relative cost of using wood as a source of household fuel rises also because of the time taken to collect it. Since four-fifths of the timber harvested in developing countries is used as household fuel, this alone could have a major beneficial impact in reducing deforestation and carbon dioxide levels.

For all these reasons, countries tend to go through an environmental transition, just as they tend to go through a demographic transition as their incomes rise. That is, instead of environmental degradation continuing to worsen as it would with output and consumption growth if no abatement policies were introduced, the extent of damage per capita tends to level off and then fall with economic growth as the government responds to demands for tougher environmental laws. Systematic evidence of the extent to which this has been happening is not yet well documented, but the recent survey by Grossman (1994) is cautiously supportive of this view.

\section{The Case of Coal}

Just as these behavioural changes are not appreciated, so the environmental effects of trade liberalisation through the relocation of production and consumption are poorly understood. It is not inevitable that a particular environmental problem will diminish as a consequence of trade reform. But that often will be the case, and all the more so if well-targeted environmental policies are introduced at the time of the liberalisation.

Consider the case of one of the world's most distorted commodity markets, namely, coal.4 As a supplier of nearly one-third of the world's energy, coal is a major contributor to local, trans-border and global environmental problems, includ-

\footnotetext{
4 Agriculture is another important case of obvious significance for Australia where trade liberalisation would probably help rather than hurt the environment. See Anderson (1992b).
} 
ing climate change and acid rain. Advanced economies in the northern hemisphere tend to restrict imports and overprice coal (while developing countries, particularly the former centrally planned economies, tend to restrict its exportation and underprice it), relative to the price in international markets (see Steenblik \& Wigley 1990; Jolly, Beck \& Savage 1990). Reducing coal price supports in the advanced economies might be expected to increase coal use and therefore worsen the environment; but not necessarily. On the contrary, if the consumer price of coal in those countries remains (or is set) at its optimal level and just the producer price is lowered to the international level, domestic coal consumption would not rise. But two other changes would improve the environment. One is that cleaner-burning imported coal could substitute for the lower-quality domestic coal, the production of which would fall. The other is that the international price of coal would rise, thereby reducing energy consumption and hence carbon emissions in the rest of the world. Since such a reform would at the same time raise real incomes, for the usual gainsfrom-trade reasons, it contrasts markedly with proposals to reduce climate change by imposing carbon taxes globally - proposals on which international agreement in any case would be extremely difficult to reach.

\section{Some Implications for Australia}

Concern for the natural environment almost certainly will increase over time, will gradually spread beyond the richest countries, and will have more of a global orientation. This, together with the increasing interdependence among the world's national economies as barriers to international trade and investment fall, ensures that even if Australia did not alter its own environmental policies, its economy will be affected by changes in other countries' environmental policies. Given our abundant natural resources, the direct effects of those changes are likely to be beneficial to Australian exporters, since they are likely to outweigh the direct effect of our own environmental policies on domestic cost structures. But there is the very real danger that those potential net benefits will be more than offset by several negative developments. These include using the environment as an excuse to raise import barriers, using trade measures to bludgeon Australia and other countries into adopting higher environmental standards than are appropriate or desired in our more spacious and lower income setting, and lobbying against trade liberalisation all of which are tending to corrode the GATT rules-based multilateral trading system on which Australia's prosperity heavily depends.

Countries will genuinely disagree on how to deal with some international environmental issues, just as groups within countries do - only more so because of wider differences in incomes and preferences between countries. The optimal solution is to be found in more negotiations, informed by results of research on the environmental as well as economic effects of alternative policies.

Despite the interest shown in it by environmental groups, the GATT (or rather its prospective replacement, the World Trade Organisation, WTO) is not the most obvious forum for such negotiations. But if it is left to do what it is designed to do, 
namely to facilitate an open, predictable, rules-based global trading system, it will indirectly foster a better use of the world's natural (and other) resources. And it will not be stopping countries implementing appropriate environmental policies within their juristrictions. Nor does GATT stop trade measures being used in international environmental agreements, so long as a dispute between GATT-contracting parties does not arise: witness their undisputed use as part of the Montreal Protocol on the phasing out of CFCs (Enders \& Porges, 1992), and in the Convention on International Trade in Endangered Species. As well, the GATT could serve as a transparency agency if contracting parties were to agree to notify the Secretariat of any new trade-related environmental measures (TREMs - a likely new word in GATT-speak).

As a small open economy outside the two major trading blocs (the European Union and the North American free-trade area), Australia relies heavily on the continued health of the multilateral trading system. Now is therefore not too soon to expand our investments in forums such as APEC and the OECD, as well as the WTO, to maximise the advantages and minimise the damage from the inevitable inter-linking of trade and environment issues. Among other things, that requires persuading environmental groups that, instead of opposing trade liberalisation and/or looking to the GATT/WTO to provide sticks to police international environmental agreements, they should advocate less costly and more effective direct measures for addressing environmental problems. But it also could include forming a group of unsubsidised coal-exporting countries, to complement the Cairns Group of lightly subsidising food-exporting countries. Both could advertise the fact that liberalising trade in those two highly distorted commodity markets (coal and food) would yield not only the conventional economic gains from trade expansion but also improvements to the environment. A coal-exporting group could also promote the idea that lowering coal-producer subsidies and import barriers offers a far more certain route to reducing carbon emissions than the less practical idea of an international agreement to impose a carbon tax.

\section{References}

Anderson, K. (1992a), 'The Standard Welfare Economics of Policies Affecting Trade and the Environment', Ch. 2 in K. Anderson \& R. Blackhurst (eds), The Greening of World Trade Issues, Harvester Wheatsheaf, London.

- (1992b), 'Agriculural Trade Liberalization and the Environment: A Global Perspective', The World Economy 15(1): 153-71.

- (1993), 'Economic Growth, Environmental Issues and Trade', in M. Noland (ed.), Pacific Dynamism and the International Economic System, Institute for International Economics, Washington, D.C.

\& R. Blackhurst (eds) (1992), The Greening of World Trade Issues, Harvester Wheatsheaf, London, and University of Michigan Press, Ann Arbor. 
Enders, A. \& A. Porges (1992), 'Successful Conventions and Conventional Success: Saving the Ozone Layer', Ch. 7 in The Greening of World Trade Issues, Harvester Wheatsheaf, London, and University of Michigan Press, Ann Arbor.

GATT (1992), Intemational Trade 199091, Volume I (Special Topic: Trade and the Environment), GATT Secretariat, Geneva.

Grossman, G. (1994), 'Pollution and Growth: What Do We Know?' in I. Goldin and L Winters (eds), The Economics of Sustainable Development, Cambridge University Press, Cambridge (forthcoming).

Jolly, L., T. Beck \& E. Savage (1990), 'Reform of International Coal Trade: Implications for Australia and World Trade', Australian Bureau of Agricultural and Resource Economics, Canberra (Discussion Paper 90.1).

Leonard, N. (1988), Pollution and the Struggle for World Product: Multinational Corporations, Environment, and Intemational Comparative Advantage, Cambridge University Press, Cambridge.

Low, P. (ed.) (1992), International Trade and the Environment, The World Bank, Washington, D.C. (Discussion Paper No. 159).

MacNeill, J., P. Winsemius \& T. Yakushiji (1991), Beyond Intendependence: The Meshing of the World's Economy and the Earth's Ecology, Oxford University Press, London.

Steenblik, R. \& K. Wigley (1990), 'Coal Policies and Trade Barriers', Energy Policy 18(4): 351-69.

Whalley, J. \& P. Uimonen (1994), Trade and the Environment: Setting the Rules, Institute for International Economics, Washington, D.C. (forthcoming).

Thanks are due to the referees for helpful comments. This article is based on a paper prepared for the televised plenary session on minerals and energy at ABARE's National Agricultural and Resources Outlook Conference, National Convention Centre, Canberra, 1-3 February 1994. 